\title{
Comparative Toxicity of "Tin Free" Self-Polishing Copolymer Antifouling Paints and Their Inhibitory Effects on Larval Development of a Non-Target Organism
}

\author{
Jane Castritsi-Catharios ${ }^{1 *}$, George Alambritis ${ }^{2}$, Helen Miliou ${ }^{3}$, Efthimia Cotou, \\ George D. Zouganelis 5 \\ ${ }^{1}$ Department of Ichthyology and Aquatic Environment, School of Agricultural Sciences, University of Thessaly, \\ Volos, Greece \\ ${ }^{2}$ National and Kapodistrian University of Athens, Department of Zoology and Marine Biology, University Cam- \\ pus, Athens, Greece \\ ${ }^{3}$ Department of Applied Hydrobiology, Faculty of Animal Science and Aquaculture, Agricultural University of \\ Athens, Athens, Greece \\ ${ }^{4}$ Hellenic Center for Marine Research, Institute of Marine Biology, Biotechnology and Aquaculture, Aghios \\ Kosmas, Hellinikon, Greece \\ ${ }^{5}$ Science, Technology, Engineering and Mathematics Centre, Bournemouth \& Poole College, Poole, UK \\ Email: "cathario@uth.gr, ${ }^{*}$ cathario@biol.uoa.gr
}

Received 22 December 2013; revised 28 January 2014; accepted 19 February 2014

Copyright () 2014 by authors and Scientific Research Publishing Inc.

This work is licensed under the Creative Commons Attribution International License (CC BY).

http://creativecommons.org/licenses/by/4.0/

(c) $\underset{\mathrm{EY}}{\mathrm{i}}$ open Access

\section{Abstract}

Toxic substances released as a result of leaching from painted surfaces to the aquatic environment affect both fouling organisms and "non-target" biota. Artemia fransiscana nauplii have been considered a useful test system for the examination of toxicity for antifouling paints. In this study, we examined the effect of four "tin free" self-polishing copolymer (SPC) antifouling paints on the larval development of Artemia nauplii. Based on the $\mathrm{L}(\mathrm{S} / \mathrm{V})_{50}$ values the order of toxicity of the antifouling paints was: ANTI F > SHARKSKIN > OCEAN T/F > MICRON. Furthermore, the body size of Artemia nauplii was significantly affected at lethal and above lethal $\mathrm{L}(\mathrm{S} / \mathrm{V})_{50^{24 h}}$ values. The body size of $48 \mathrm{~h}$-aged nauplii exposed for the last 24 hours to each of the four SPC antifouling paints was significantly lower than that of the $48 \mathrm{~h}$-aged controls $(0.88 \pm 0.030 \mathrm{~mm})$. In addition, the body size of $72 \mathrm{~h}$-aged nauplii maintained for the last 24 hours to pure synthetic seawater after exposure for 24 hours to each of the four SPC antifouling paints was significantly lower than that of the $72 \mathrm{~h}$-aged controls $(0.96 \pm 0.027 \mathrm{~mm})$. Overall, the SPCs examined here were substantially

\footnotetext{
${ }^{*}$ Corresponding author.
} 
toxic to Artemia nauplii, but with different toxicities and modes of action, as a result of the synergistic action of distinct components of the antifouling paints.

\title{
Keywords
}

\author{
Artemia fransiscana Nauplii; “Tin Free” Self-Polishing Copolymer; Antifouling Paints; Body Size
}

\section{Introduction}

Artemia populations inhabit about 500 salt lakes and salt works of temperate, subtropical and tropical zones [1]. These include sizable lakes such as the Great Salt Lake (GSL) and the Caspian Sea, where sailing activity and a wide range of underwater structures exist.

Antifouling paints are used to control the growth of biofouling on ship and yacht hulls, oil rigs, cofferdams and cages of aquaculture, sonar equipment, underwater pipes and docks. Biofouling can be defined as a natural phenomenon of the undesirable accumulation of microorganisms, such as bacteria and microalgae, plants and invertebrates on artificial surfaces submerged in seawater [2]. The first written reference of the phenomenon is attributed to the ancient Greek philosopher Aristotle (4th century BC) who observed that boat speed reduction may occur due to the attachment of barnacles on the boat's hull.

To this day it is a significant problem for shipping and yachting industry worldwide because it reduces the speed of the vessel and durability and increases costs of fuel consumption. For several decades many forms and compositions of antifouling paints have been manufactured and used in the market to control biofouling. The use of toxic antifoulants on ship hulls has been a historic method and biocides such as lime, arsenical, mercurial, DDT compounds and their organic derivates were used as antifoulants to coat ship's hulls, but they were banned due to the environmental risks that they posed. In the 20th century a revolutionary self-polishing copolymer (SPC) technique employing a similar heavy metal toxic action to deter biofouling was developed with the antifoulant tributyltin (TBT) [3] that quickly dominated the markets for many decades, as it played a major role in both reducing the effects of biofouling and improving the economy of the shipping industry. Since the early eighties, however, the undesired effects of organotin compounds on marine non-target organisms the so-called "imposex condition" and the reduced reproduction in field populations were realized [4]-[7]. Dimitriou et al. [8] studied the effects of TBTCl \& TPhTCl in fertilized eggs of Sparus aurata with acute toxicity static tests and reconfirmed the toxicity of this toxic substances ever introduced deliberately into the marine environment [9]. Moreover, tin bioaccumulated in some ducks, seals and fish [10] [11] and the use of TBTs was eventually banned in 2008 according to legislation that culminated in the global ban of TBTs [12].

As a consequence of that restriction "tin free" paint systems with SPC techniques were developed. SPCs are acrylic copolymers with pendant hydrolysable function and a variable hydrophobic/hydrophilic balance. Most of these "tin free" paint systems rely on the use of sea water soluble pigments such as copper oxides $\left(\mathrm{Cu}_{2} \mathrm{O}, \mathrm{CuO}\right)$, copper thyocyanate (CuSCN) or zinc oxide ( $\mathrm{ZnO}$ ) in combination with boosting co-biocides for biofouling control, in which seawater penetration is essential to the biocides release [13]. Currently, the most popular booster biocides are Irgasol 1051 (s-Triazine group), Dichlofluanid, Diuron, Sea-nine 211, Chlorothalonil, TCMS pyridine, TCMTB, Zinc pyrithione, Copper pyrithione, Benzmethylamide, Mancozeb, Polyphase, Pyridine-triphenyl-borane, Thiram, Tolyfluanid, Ziram and Zineb [2] [14] [15].

However, this alternative solution (i.e. from TBT to tin free with soluble pigments and booster biocides) has been a topic of increasing importance due to contamination of the aquatic environment [16] [17]. It has also been found that organic booster biocides may be toxic to non-target organisms [18] [19].

The approval system in the European Union for the antifouling paints is controlled by the Biocidal Products Directive (BPD) [20] and the toxic hazard has been focused mainly on the active substances [21]-[24]. However, apart from active substances the antifouling paints also contain binders, solvents and preservatives, which by themselves can also have toxic effects. Recent studies have indicated the important role of fillers and binders in the formulation and the amount of biocides released [25] [26], which may influence the toxic effects of the antifouling paints on non-target organisms. The importance to test each product (antifouling paint) as a whole to discover possible synergistic effects that influence their toxicity has been demonstrated [19] [27]. Several tests 
and models have been developed (e.g. ISO 15181), with which one can estimate the release of biocides and the other ingredients from the antifouling paints. The leaching properties of further bioactive compounds in antifouling paints may be influenced by the formulation, and pigment solubility has been earmarked to have a significant influence on the polishing and leaching behaviour of a self-polishing paint [28]. However, only few studies have estimated the toxicity of the product as a whole [19] [27] [29]-[31]. The present study is a further contribution to this subject and compares the toxicity of four "tin free" SPC antifouling products as a whole on a non-target organism, the brine shrimp Artemia franciscana, using a new developed coating/leaching technique to test toxicity of antifoulants [31]. Besides mortality, the effects on body growth of the test species have also been determined. The importance of using A. franciscana to evaluate the potential effects of SPCs is twofold. On the one hand, to reinforce its application in subacute biotests for developmental studies, as it has previously been suggested [1]. On the other hand, A. franciscana has a significant commercial value for the local economies, particularly for GSL that is one of its primary habitats. It is estimated that approximately 10 million pounds of brine shrimp eggs are harvested each winter and sold as food for tropical fish. The commercial shrimp industry generates over $\$ 10$ million annually to the local economy and represents $90 \%$ for the world's comercial harvest. Brine shrimp in GSL may be at risk from SPCs, as it has previously been mentioned for the toxicity effects of certain heavy metals [32].

\section{Experimental Procedures}

\subsection{Antifouling Paints}

The four SPC antifouling paints used for the study were Sharkskin, Ocean T/F (Dark 3280), Micron (Extra Navy Blue) and Anti F, and were purchased from the Greek market. These paints are considered to be "tin free", so they are allowed for usage on ships leisure boats and underwater structures in Greece. All four SPC antifouling paints differ in their formulation, ingredients and pigments. Apart from the active biocides, the paints contain binders, solvents and preservatives, which by themselves may also have toxic effects on non-target organisms. The exact chemical composition of these paints is not supplied by the manufacturer and only few data are available (Table 1).

\subsection{Test Organisms}

The non-target brine shrimp A. franciscana has been used as test organism. Artemia is a euryhaline crustacean found in salt lakes and salt pans in marine environments and is considered as a popular test animal for acute toxicity testing because of its ease of culture, short generation time, cosmopolitan distribution and the comercial availability of dormant eggs (cysts). Since test animals hatched from cysts are of similar age, genotype and physiological condition, test variability is greatly reduced [33].

\subsection{Testing Method}

Commercially available dry cysts of $A$. franciscana were hatched in synthetic seawater (Instant Ocean sea salt). Artemia nauplii of instar II-III stages were used to determine the toxicity of each antifouling paint and its effect on the body size of the organism. An improved method of Castritsi-Catharios et al. [31] was applied in order to obtain different antifouling paints concentrations. The latter were achieved by combining a constant antifouling coated piston surface of syringes filled with different volume of synthetic seawater.

In the present study, $10-\mathrm{mL}$ syringes with $200 \mathrm{~mm}^{2}$ piston surface were used. The relationship of coated

Table 1. Information about the four commercial "tin free" SPC antifouling paints labelled in the product.

\begin{tabular}{cccc}
\hline Product Name & Producer & Active ingredients-Biocides & Other ingredients \\
\hline MICRON (Extra Navy Blue) & International & $\mathrm{CuO}(90.3 \mathrm{~g} / \mathrm{L})$ Dichlofluanid $(16.8 \mathrm{~g} / \mathrm{L})$ & Colophon Rosin H.S.E \\
OCEAN T/F (DARK 3280) & EN PLO & $\mathrm{Cu}_{2} \mathrm{O}$ Tolyfluanid & Xylene Gum Rosin \\
SHARSKIN & Syntex & $\mathrm{CuSCN}(42.2 \%)$, Diuron & Xylene (26.6\%) Toluene (2\%) \\
ANTI F & Neotex & $\mathrm{Cu}_{2} \mathrm{O}(41 \%)$, Diuron (2\%) & \\
\hline
\end{tabular}


surface $(\mathrm{S})$ to volume of seawater $(\mathrm{V})$ was expressed as $\mathrm{S} / \mathrm{V}$ units. The lowest $\mathrm{S} / \mathrm{V}$ unit in this study was 20 $\mathrm{mm}^{2} / \mathrm{mL}$ and the highest $100 \mathrm{~mm}^{2} / \mathrm{mL}$.

\subsection{Determination of Toxicity}

Instead of the conventional method in which $\mathrm{LC}_{50}$ values are calculated based on $50 \%$ mortality of the test organisms, in this study the S/V concept of Persoone and Castritsi-Catharios [34] was applied with determination of the $\mathrm{L}(\mathrm{S} / \mathrm{V})_{50}$ values. The $\mathrm{L}(\mathrm{S} / \mathrm{V})_{50}$ is the surface $(\mathrm{S})$ to volume $(\mathrm{V})$ ratio which induces $50 \%$ mortality of the test organisms. This method inherently incorporates the "surface" aspect of coatings and is therefore more representative and meaningful for studies which aim at evaluating the toxicity of underwater coated surfaces.

Specifically, LC(S/V $)_{50}{ }^{24 \mathrm{~h}}$ was calculated for each of the four SPC antifouling paints after exposure of 24 h-aged nauplii (Instar II-III) for 24 hours to different S/V units (24 h-treatment), as well as LC(S/V/) ${ }_{50}^{48 \mathrm{~h}}$ after subsequent maintenance for additional 24 hours to pure synthetic seawater (48 h-treatment).

\subsection{Body Size Analysis}

Artemia nauplii of $24 \mathrm{~h}$-aged (Instar II-III) were exposed for 24 hours to antifouling solutions with concentrations higher, equal or lower than that of $\mathrm{L}(\mathrm{S} / \mathrm{V})_{50}{ }^{24 \mathrm{~h}}$. The animals which survived after this exposure (without exhibiting morphological or mobility problems) were transferred in pure synthetic seawater, where they were maintained for additional 24 hours. Thus, the body length of the $48 \mathrm{~h}$ - or $72 \mathrm{~h}$-aged nauplii after the $24 \mathrm{~h}$ - or 48 h-treatment, respectively, was measured under a stereoscope (ZEIS 474057) with calibrated oculars. The body length of respective controls was also estimated. It was meaningless to extend the duration of the test since in naulpii aged more than 72 hours the yolk sack is absorbed and, if the animals are not fed, increased mortality is observed [35].

\subsection{Statistical Analysis}

The $\mathrm{L}(\mathrm{S} / \mathrm{V})_{50}$ for each SPC antifouling paint was calculated by the linear regression equation $\mathrm{Y}=\mathrm{a}+\mathrm{bX}$, where $\mathrm{Y}=$ mortality (\%) and $\mathrm{X}=\mathrm{S} / \mathrm{V}$ units $\left(\mathrm{mm}^{2} / \mathrm{mL}\right)$. Comparison of regression lines was performed to test for statistically significant differences between the intercepts and/or the slopes $(P<0.05)$ after the $24 \mathrm{~h}$ - or 48 h-treatment. One-way analysis of variance (ANOVA) was carried out on biometry data: 1) among the different S/Vs of the same antifouling paint for $48 \mathrm{~h}$ - or $72 \mathrm{~h}$-aged nauplii, 2) among the different antifouling paints at the same $\mathrm{S} / \mathrm{V}$ for $48 \mathrm{~h}$ - or $72 \mathrm{~h}$-aged nauplii and 3) between $48 \mathrm{~h}$ - and $72 \mathrm{~h}$-aged nauplii at the same $\mathrm{S} / \mathrm{V}$ and antifouling paint. Multiple range test (Bonferroni) was applied to determine statistically significant differences $(P<0.05)$. In addition, the linear regression equation of body size versus $\mathrm{S} / \mathrm{V}$ was estimated for each of the four antifouling paints. Comparison of regression lines was conducted among the four antifouling paints for the nauplii of the same age, as well as between the $48 \mathrm{~h}$ - and $72 \mathrm{~h}$-aged nauplii of the same antifouling paint. Prior to ANOVA or regression analysis, data were assessed for homogeneity of variance (Cochran's and Bartlett's tests) and normal distribution (Kolmogorov). In all the comparisons of regression lines, the Durbin-Watson values were greater than 1.4 indicating that there was probably not any serious autocorrelation in the residuals. $\mathrm{R}^{2}$ adjusted for degrees of freedom is presented. All analyses were performed using Statgraphics Plus version 4 (Manugistics Group, Inc.).

\section{Results and Discussion}

The four SPC antifouling paints indicated different patterns of toxicity after the 24 h- (Figure 1(a)) or 48 htreatment (Figure 1(b)) of 24 h-aged Artemia naulpii.

The correlation coefficient (r) for every linear regression equation of each antifouling paint ranged from 0.81 to 0.94 (Tables 2 and 3) indicating a moderately or relatively strong relationship. All the estimated models appeared to be adequate for the observed data, since the P-values of lack-of-fit were greater of 0.10 . Based on the $\mathrm{L}(\mathrm{S} / \mathrm{V})_{50}$ values after the $24 \mathrm{~h}$ - or $48 \mathrm{~h}$-treatment, the toxicity of the four antifouling paints was in the following order: ANTI F $>$ SHARKSKIN $>$ OCEAN T/F $>$ MICRON (Tables 2 and 3).

Comparison of regression lines representing mortality (\%) versus $\mathrm{S} / \mathrm{V}\left(\mathrm{mm}^{2} / \mathrm{mL}\right)$ of the antifouling paints showed statistically significant differences between the intercepts and in some cases between the slopes as well (Table 4). An exception was observed between the regression lines estimated for ANTI F and SHARSKIN after 

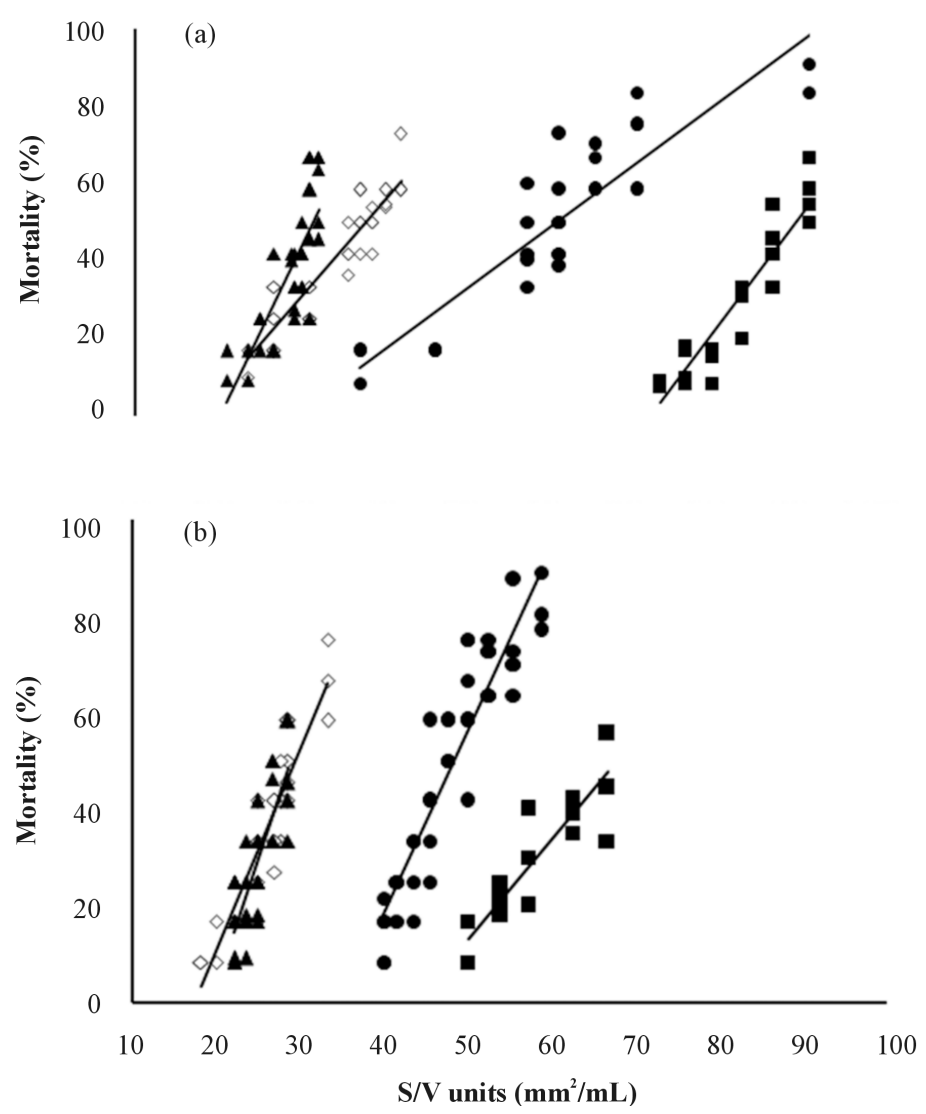

Figure 1. Comparative toxicities of four "tin free" SPC antifouling paints after: (a) Exposure for 24 hours of 24 h-aged Artemia nauplii and (b) Subsequent maintenance for additional 24 hours in pure synthetic seawater.

Table 2. Toxicity estimation of four commercial "tin free” SPC antifouling paints [characteristics of linear regression equations and $\mathrm{L}(\mathrm{S} / \mathrm{V})_{50}$ values] after exposure for 24 hours of 24 h-aged Artemia nauplii.

\begin{tabular}{|c|c|c|c|c|c|c|c|c|}
\hline & \multirow{2}{*}{$\mathbf{a}$} & \multirow{2}{*}{ b } & \multirow{2}{*}{$\mathbf{r}$} & \multirow{2}{*}{$\mathbf{R}^{2}$} & \multirow{2}{*}{$\boldsymbol{P}_{\mathrm{b}}$} & \multirow{2}{*}{$\mathrm{L}(\mathrm{S} / \mathrm{V})_{50}{ }^{24 \mathrm{~h}}$} & \multicolumn{2}{|c|}{ 95\% conf. limits } \\
\hline & & & & & & & Lower & Upper \\
\hline SHARKSKIN & -41.825 & 2.257 & 0.923 & 85.28 & $* * *$ & 40.68 & 39.73 & 41.63 \\
\hline OCEAN T/F & -44.706 & 1.429 & 0.901 & 81.26 & $* * *$ & 66.26 & 63.56 & 68.96 \\
\hline ANTI F & -86.705 & 4.062 & 0.807 & 65.25 & $* * *$ & 33.65 & 32.42 & 34.88 \\
\hline MICRON & -202.688 & 2.575 & 0.945 & 89.32 & $* * *$ & 98.13 & 96.61 & 99.65 \\
\hline
\end{tabular}

a: intercept, b: slope, r: correlation coefficient, $P_{\mathrm{b}}$ : $P$-value for slope; ${ }^{* * *} P_{\mathrm{b}} \leq 0.0001$.

the 48 h-treatment which had equal intercepts and slopes.

The body size of $48 \mathrm{~h}$-aged nauplii exposed for the last 24 hours to each of the four SPC antifouling paints (24 h-treatment) was significantly lower than that of the $48 \mathrm{~h}$-aged controls $(0.88 \pm 0.030 \mathrm{~mm})$. Within the range of the $\mathrm{S} / \mathrm{V}$ units tested for each antifouling paint, the body size was significantly affected only at the $\mathrm{L}(\mathrm{S} / \mathrm{V})_{50}{ }^{24 \mathrm{~h}}$ (OCEAN T/F and MICRON) or above this (SHARKSKIN and ANTI F) (Table 5).

At $50 \mathrm{~S} / \mathrm{V}$ units, the body size of $48 \mathrm{~h}$-aged nauplii exposed to SHARKSKIN, ANTI F or OCEAN T/F was similar, but significantly $(P<0.0001)$ lower than that of 48 h-aged nauplii exposed to MICRON. No significant differences were found in the body size between the antifouling paints at the lower S/V units tested, while at the 
Table 3. Toxicity estimation of four commercial "tin free” SPC antifouling paints [characteristics of linear regression equations and $\mathrm{L}(\mathrm{S} / \mathrm{V})_{50}$ values] after exposure for 24 hours of 24 h-aged Artemia nauplii and subsequent maintenance for additional 24 hours in pure synthetic seawater.

\begin{tabular}{|c|c|c|c|c|c|c|c|c|}
\hline & \multirow{2}{*}{$\mathbf{a}$} & \multirow{2}{*}{ b } & \multirow{2}{*}{$\mathbf{r}$} & \multirow{2}{*}{$\mathbf{R}^{2}$} & \multirow{2}{*}{$\boldsymbol{P}_{\mathrm{b}}$} & \multirow{2}{*}{$\mathrm{L}(\mathrm{S} / \mathrm{V})_{50}{ }^{48 \mathrm{~h}}$} & \multicolumn{2}{|c|}{$95 \%$ conf. limits } \\
\hline & & & & & & & Lower & Upper \\
\hline SHARKSKIN & -72.354 & 4.154 & 0.913 & 83.29 & $* * *$ & 29.45 & 28.64 & 30.26 \\
\hline OCEAN T/F & -133.212 & 3.789 & 0.922 & 86.00 & $* * *$ & 48.35 & 47.60 & 49.10 \\
\hline ANTI F & -103.699 & 5.320 & 0.813 & 66.08 & $* * *$ & 28.89 & 27.69 & 30.09 \\
\hline MICRON & -91.155 & 2.084 & 0.908 & 82.36 & $* * *$ & 67.74 & 65.51 & 68.71 \\
\hline
\end{tabular}

a: intercept, b: slope , r: correlation coefficient, $P_{\mathrm{b}}$ : $P$-value for slope; ${ }^{* * *} P_{\mathrm{b}} \leq 0.0001$.

Table 4. Comparison of linear regression lines (slopes \& intercepts) for mortality (\%) versus S/V units (mm²/mL) of four commercial "tin free” SPC antifouling paints after 24 h- or 48 h-treatment (characteristics of the regression equations are given in Tables 2 and 3, respectively).

\begin{tabular}{|c|c|c|c|c|}
\hline & ANTI F & MICRON & OCEAN T/F & SHARKSKIN \\
\hline \multicolumn{5}{|l|}{24 h-treatment } \\
\hline ANTI F & - & - & - & - \\
\hline MICRON & $0.0055^{1}(0.0000)^{2}$ & - & - & - \\
\hline OCEAN T/F & $0.0000(0.0000)$ & $0.0001(0.0000)$ & - & - \\
\hline SHARKSKIN & $0.0003(0.0000)$ & $0.1819(0.0000)$ & $0.0008(0.0000)$ & - \\
\hline \multicolumn{5}{|l|}{48 h-treatment } \\
\hline ANTI F & - & - & - & - \\
\hline MICRON & $0.0000(0.0000)$ & - & - & - \\
\hline OCEAN T/F & $0.0442(0.0000)$ & $0.0000(0.0000)$ & - & - \\
\hline SHARKSKIN & $0.1057(0.3932)$ & $0.0000(0.0000)$ & $0.4190(0.0000)$ & - \\
\hline
\end{tabular}

${ }^{1} P$-value for slope, ${ }^{2} P$-value for intercept.

higher S/V units the body size of $48 \mathrm{~h}$-aged nauplii exposed to OCEAN T/F was significantly $(P<0.0001)$ lower compared to MICRON. The linear regression lines of body size (Y) versus S/V (X) estimated for 48 h-aged nauplii (Figures not shown) exposed to SHARKSKIN, ANTI F or OCEAN T/F were similar between them, as concerning both the intercept and the slope $\left(\mathrm{Y}=0.876-0.004 \mathrm{X}, \mathrm{R}^{2}=88.46 \%\right)$. The linear regression line for $48 \mathrm{~h}$-aged nauplii exposed to MICRON declined with a significantly $(P<0.0001)$ lower slope $(\mathrm{Y}=$ $0.878-0.002 X, \mathrm{R}^{2}=90.50 \%$ ).

The body size of 72 h-aged nauplii maintained for the last 24 hours to clean seawater after exposure for 24 hours to each of the four SPC antifouling paints (48 h-treatment) was significantly lower than that of the $72 \mathrm{~h}$ aged controls $(0.96 \pm 0.027 \mathrm{~mm})$. In addition, it was significantly higher than that of the $48 \mathrm{~h}$-aged nauplii (24 htreatment) exposed for the last 24 hours to the respective antifouling paint (Table 4). However, the differentiation in the body size of $72 \mathrm{~h}$-aged nauplii among the four SPC antifouling paints at the same S/V units was similar compared to that of $48 \mathrm{~h}$-aged nauplii. The linear regression models (Figures not shown) describing the decrease in the body size $(\mathrm{Y})$ of 72 h-aged nauplii with increasing the S/V (X) of SHARKSKIN, ANTI F, OCEAN T/F $\left(\mathrm{Y}=0.967-0.003 \mathrm{X}, \mathrm{R}^{2}=84.17 \%\right)$ or MICRON $\left(\mathrm{Y}=0.957-0.002 \mathrm{X}, \mathrm{R}^{2}=85.24 \%\right)$ showed a significantly $(P<0.0001)$ higher intercept, but a similar slope, compared to the aforementioned equations for 48 h-aged nauplii exposed to the respective antifouling paints.

The "tin-free" SPC antifouling products were found to be substantially toxic to the non-target Artemia nauplii. The calculated $\mathrm{L}(\mathrm{S} / \mathrm{V})_{50}$ values and the linear regression models indicated different toxicities and different mode 
Table 5. Body size effects (mean \pm standard deviation) on 24 h-aged Artemia nauplii after exposure for 24 hours (48 h-aged nauplii) to lethal and sub-lethal concentrations of four commercial "tin free" SPC antifouling paints and subsequent maintenance for additional 24 hours in pure synthetic seawater (72 h-aged nauplii). $\mathrm{N}=20$ - 25 for each case.

\begin{tabular}{|c|c|c|c|c|}
\hline & & Body size (mm) & & $P$-value for $\mathrm{S} / \mathrm{V}$ \\
\hline \multicolumn{5}{|l|}{ SHARKSKIN } \\
\hline $\mathrm{S} / \mathrm{V}\left(\mathrm{mm}^{2} / \mathrm{mL}\right)$ & 33.33 & 40 & 50 & \\
\hline$\underline{48 \text { h-aged nauplii }}$ & $0.73 \pm 0.019^{a}$ & $0.72 \pm 0.019^{\mathrm{a}}$ & $0.68 \pm 0.020^{\mathrm{b}}$ & $* * *$ \\
\hline$\underline{72 \mathrm{~h} \text {-aged nauplii }}$ & $0.85 \pm 0.035^{\mathrm{a}}$ & $0.82 \pm 0.043^{\mathrm{a}}$ & $0.74 \pm 0.040^{\mathrm{b}}$ & $*$ \\
\hline$P$-value for hours & $* * *$ & $* * *$ & $*$ & \\
\hline \multicolumn{5}{|l|}{ MICRON } \\
\hline $\mathrm{S} / \mathrm{V}\left(\mathrm{mm}^{2} / \mathrm{mL}\right)$ & 50 & 66.66 & 100 & \\
\hline$\underline{48 \text { h-aged nauplii }}$ & $0.76 \pm 0.020^{\mathrm{a}}$ & $0.75 \pm 0.017^{\mathrm{a}}$ & $0.69 \pm 0.019^{\mathrm{b}}$ & $* * *$ \\
\hline$\underline{72 \mathrm{~h} \text {-aged nauplii }}$ & $0.85 \pm 0.028^{\mathrm{a}}$ & $0.84 \pm 0.023^{\mathrm{a}}$ & $0.80 \pm 0.017^{\mathrm{b}}$ & ** \\
\hline$P$-value for hours & $* * *$ & $* * *$ & $* * *$ & \\
\hline \multicolumn{5}{|l|}{ OCEAN T/F } \\
\hline $\mathrm{S} / \mathrm{V}\left(\mathrm{mm}^{2} / \mathrm{mL}\right)$ & 40 & 50 & 66.66 & \\
\hline$\underline{48 \text { h-aged nauplii }}$ & $0.71 \pm 0.033^{\mathrm{a}}$ & $0.71 \pm 0.035^{\mathrm{a}}$ & $0.64 \pm 0.032^{\mathrm{b}}$ & ** \\
\hline$\underline{72 \mathrm{~h} \text {-aged nauplii }}$ & $0.85 \pm 0.021^{\mathrm{a}}$ & $0.79 \pm 0.013^{\mathrm{b}}$ & $0.76 \pm 0.018^{\mathrm{b}}$ & $* *$ \\
\hline$P$-value for hours & $* * *$ & $* *$ & $* * *$ & \\
\hline \multicolumn{5}{|l|}{ ANTI F } \\
\hline $\mathrm{S} / \mathrm{V}\left(\mathrm{mm}^{2} / \mathrm{mL}\right)$ & 28.57 & 33.33 & 50 & \\
\hline$\underline{48 \text { h-aged nauplii }}$ & $0.74 \pm 0.021^{\mathrm{a}}$ & $0.74 \pm 0.021^{\mathrm{a}}$ & $0.70 \pm 0.016^{\mathrm{b}}$ & *** \\
\hline$\underline{72 \mathrm{~h} \text {-aged nauplii }}$ & $0.91 \pm 0.010^{\mathrm{a}}$ & $0.88 \pm 0.030^{\mathrm{b}}$ & $0.77 \pm 0.024^{\mathrm{c}}$ & $* * *$ \\
\hline$P$-value for hours & ${ }^{* * *}$ & $* * *$ & $* * *$ & \\
\hline
\end{tabular}

Mean values in the same row with different letter in superscript are significantly different. $P$-values: ${ }^{*} P<0.05,{ }^{* *} P<0.001,{ }^{* * *} P<0.0001$.

of actions, respectively, for each of the antifouling product (Tables 2-4, Figure 1). Moreover, the body growth of Artemia nauplii was significantly inhibited at the $\left(\mathrm{L}(\mathrm{S} / \mathrm{V})_{50}{ }^{24 \mathrm{~h}}\right.$ or above this (Table 5). The most toxic product appeared to be the ANTI F and the less toxic the MICRON. Considering each paint formulation and composition results pointed out that the different toxicities and mode of actions were mainly attributed to the different ingredients and their amounts included in the antifouling products. Apart from the presence of the copper, the presence of the different booster biocides as well as the other ingredients in the formulated matrices used to control the release of the bioactive compounds appeared to influence paints toxicity.

The toxicity of copper in water is greatly affected by its speciation with the free copper ions considered as the most bioavailable and thus most toxic [36] [37]. Diuron toxicity is temperature and salinity dependant [38]. Diuron toxicity $\mathrm{LC}_{50}{ }^{24 \mathrm{~h}}$ values for Artemia at salinity 35\%o had been 11.42 to $12.6 \mathrm{mg} / \mathrm{L}$ [39]. Joint effects have been demonstrated in acute toxicity tests of binary mixtures of Diuron or Dichofluanid with copper [40] [41].

The decomposition of antifouling paints release copper in soluble ionic forms. The release of antifouling compounds from a coating surface can be controlled by using either a soluble or insoluble matrix [42]. Controlled dissolution of antifouling compounds is difficult and copper toxicity is under recent inspection [43]. Yebra et al. [44] have investigated the release rates of commercial rosin binders as effective methods to control this dissolution. Solubility of rosin and hence antifouling effectiveness is favoured by alkaline, high salt content and oxidative conditions. The effect of rosin compounds to crustaceans have been considered mild, however a small but statistically significant decrease in size of Daphnia growth at the end of exposure to rosin components has 
been recorded at concentrations as low as $0.5 \mathrm{mg} / \mathrm{L}$ [45].

Booster biocides have been incorporated in antifouling paints to increase the length and functionality of copper-based antifouling coating systems, since their usage could provide an interim solution in response to the demands for an effective antifouling strategy of TBT replacement [46]. In the formulation of ANTI F booster biocide Diuron is included, while MICRON contains the booster biocide Dichlofluanid. Diuron [3-(3,4-dichlorophenyl)-1,1-dimethylurea] is a substituted urea-based herbicide employed principally for the control of vegetation in non-crop areas since the 1950s, but it is also used as booster biocide in antifouling paints [2]. It has been reported to be relative persistent in seawater [47], considerably stable to hydrolysis [48], and relatively soluble in water [(35 mg/L) (log Kow of 2.8, log Koc of 2.3 - 5.2 and a Kd of 8.9)] [14] [49]. Therefore, it has been suggested that Diuron will be predominantly found in the dissolved phase. The occurrence of Diuron as an antifouling agent has been reported in a number of European countries and Japan, but is no longer approved for use in the UK as an active ingredient in antifouling paints on any size of vessel [15]. Biological effects of Diuron in non-target organisms have been demonstrated in the inhibition of hatching of Artemia cysts and molecular binding of the inhibitor to the active site of the hatching enzyme has been proposed [50]. On the other hand, Dichlofluanid (N-dichlorofluoromethylthio-N',N'-dimethyl-N-phenylsulfamide) is a fungicide, much less soluble in water $(<2 \mathrm{mg} / \mathrm{L})$ with a high octanol/water partition coefficient $(\log$ Kow $=3.7)$, thus it is thought to rapidly undergo hydrolysis to form N,N-dimethyl-N'-phenylsulphamide (DMSA) [50] with a half-life in seawater of $<20 \mathrm{~h} \mathrm{[14]} \mathrm{[51]} \mathrm{and} \mathrm{it} \mathrm{has} \mathrm{been} \mathrm{found} \mathrm{the} \mathrm{most} \mathrm{strongly} \mathrm{bound} \mathrm{biocide} \mathrm{in} \mathrm{sediments} \mathrm{compared} \mathrm{to} \mathrm{Diuron} \mathrm{[52]}$ [53]. Diuron exhibited the least preference for sorptive behavior compared to Dichlofluanid [53]. However, no detectable concentrations of Dichlofluanid have been measured in any of the seawater and sediment samples of Greek marinas since it is known its high hydrolytic and degradation rate [54].

Inhibition of growth has been described for other crustacean species after exposure to copper [55] [56]. Especially, chronic exposure to sub-lethal concentrations of copper has significantly reduced the total length of decapoda Farfantepenaeus paulensis postlarvae [56]. Chronic effects of Diuron have also shown to inhibit the growth (total length) of the amphipod Hyalella azteca and the embryo/larvae of the fathead minnow Pimephales promelas at concentrations above the lowest observed adverse effect levels [57]. Kerster \& Schaeffer [58] used Artemia nauplii to establish a "teratogen test" related to effects of metals on length. The test was based on disruption of elongation between 24 and 48 hours after wetting of the cysts when testing several heavy metals. This phenomenon is probably due to the inhibition of molting [59]. Our findings show that the experimental animals continue to exhibit a disturbance of the elongation development, relatively to the controls, in subsequent developmental stages even after maintenance of the test animals to pure synthetic water after their exposure to different S/V units of the four SBCs. According to Diagram 1, a third or a fourth molt may occur during the first or the second 24 h-period, respectively, in the 48 h-treatment of control animals. However, the $72 \mathrm{~h}$-aged naulpii exposed to $\mathrm{S} / \mathrm{Vs}$ of the four SBCs higher or equal to their respective $\mathrm{S} / \mathrm{V}_{50}{ }^{24 \mathrm{~h}}$ showed a body size similar or lower to that of the $48 \mathrm{~h}$-aged controls. Since the experimental animals were maintained in pure synthetic seawater for the last 24 hours, the disturbance of their elongation was probably due the former 24 h-exposure to the aforementioned S/Vs of the four SBCs resulting to a prolongation of the time period required for the third molting.

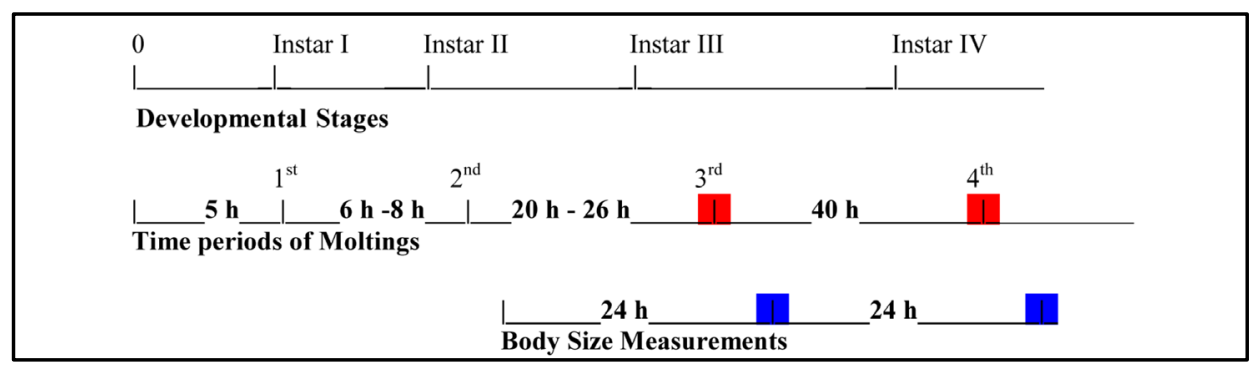

Blue marks represent the endpoint measurements of the body size after the first 24 h-period (different S/Vs of the four SBCs or pure seawater for controls) and the second 24 h-period (pure seawater for all specimen). Nauplii were 24 haged at the beginning of the former period, while they were 72 h-aged at the end of the second one; red marks represent the molts that may occur during the 48 h-treatment in the controls.

Diagram 1. Developmental stages of Artemia nauplii (Instars I-IV), respective time periods of moltings $\left(1^{\text {st }}-4^{\text {th }}\right)$ occurring after hatching of the cysts and body size measurements. 
It would be very interesting to extend the experiments up to the next generation, in order to determine any epigenesis, after short exposure in a toxic solution followed by transfer to pure water for the remaining time period.

\section{Conclusion}

The current work provides novel data on biological effects for four "tin free" SPC antifouling paints on Artemia nauplii development. The results suggest that naupliar development can be used as an easily measurable parameter for acute or chronic toxicity tests, even in sublethal concentrations. Our study strengthens the view that the well-established fact for the estimation of the toxicity of antifouling paints tested to the product as a whole is toxicologically important since all ingredients, either biocides or booster biocide, and other agents for controlling leaching rates included in the formulation can influence antifoulants toxicity as they have synergistic effects. Such effects cannot be estimated in single toxicity testing of the biocide agents or of other substances included in the formulation of a "tin free" SPC antifouling product.

\section{Acknowledgements}

We would like to kindly thank Prof. Dr. G. Persoone for his valuable suggestions and corrections.

\section{References}

[1] Dvořák, P., Žd’árský M. and Beňová, K. (2009) Possibilities of the Alternative Generation II Biotests at Artemia. Interdisciplinary Toxicology, 2, 45-47.

[2] Yebra, D.M., Kill, S. and Dam-Johansen, K. (2004) Antifouling Technology: Past, Present and Future Steps towards Effi- cient and Environmentally Friendly Antifouling Coatings. Progress in Organic Coatings, 50, 75-104. http://dx.doi.org/10.1016/j.porgcoat.2003.06.001

[3] Gerigk, U., Schneider, U. and Stewen, U. (1998) The Present Status of TBT Copolymer Antifouling Paints versus TBT-Free Technology. Preprints of Extended Abstracts, ACS National Meeting, 38, 91-94.

[4] Smith, B.S. (1981) Male Characteristics on Female Mud Snails Caused by Antifouling Bottom Paints. Journal of Applied Toxicology, 1, 22-25. http://dx.doi.org/10.1002/jat.2550010106

[5] Bryan, G.W., Gibbs, P.E., Hummerstone, L.G. and Burt, G.R. (1986) The Decline of the Gastropod Nucella Lapillus around South-West England: Evidence for the Effect of Tributyltin from Anti-Fouling Paints. Journal of the Marine Biological Association of the United Kingdom, 66, 611-640. http://dx.doi.org/10.1017/S0025315400042247

[6] Fent, K. (1996) Ecotoxicology of Organotin Compounds. Critical Reviews in Toxicology, 26, 1-117. http://dx.doi.org/10.3109/10408449609089891

[7] Vos, J.G., Dybing, E., Greim, H.A., Ladefoged, O., Lambre, C., Tarazona, J.V., Brandt, I. and Vethaak, A.D. (2000) Health Effects of Endocrine-Disrupting Chemicals on Wildlife, with Special Reference to the European Situation. Critical Reviews in Toxicology, 30, 71-133. http://dx.doi.org/10.3109/10408449609089891

[8] Dimitriou, P., Castritsi-Catharios, J. and Miliou, H. (2003) Acute Toxicity Effects of Tributyltin Chloride and Triphenyltin Chloride on Gilthead Seabream, Sparus aurata L., Embryos. Ecotoxicology and Environmental Safety, 54, 3035. http://dx.doi.org/10.1016/S0147-6513(02)00008-8

[9] Mee, L.D. and Fowler, S.W. (1991) Organotin Biocides in the Marine Environment: A Managed Transient? Marine Environmental Research, 32, 1-5. http://dx.doi.org/10.1016/S0147-6513(02)00008-8

[10] Morcillo, Y., Borghi, V. and Porte, C. (1997) Survey of Organotin Compounds in the Western Mediterranean Using Molluscs and Fish as Sentinel Organisms. Archives of Environmental Contamination and Toxicology, 32, $198-203$. http://dx.doi.org/10.1007/s002449900175

[11] Shawky, S. and Emons, H. (1998) Distribution Pattern of Organotin Compounds at Different Trophic Levels of Aquatic Ecosystems. Chemosphere, 36, 523-535. http://dx.doi.org/10.1007/s002449900175

[12] (2002) Focus on IMO: Antifouling Systems. International Maritime Organization, London.

[13] Avai, T., Harino, H., Ohji, M. and Langston, W.J. (2009) Ecotoxicology of Antifouling Biocides. Springer, Springer Verlag, Berlin.

[14] Thomas, K.V. (2001) The Environmental Fate and Behavior of Antifouling Paint Booster Biocides: A Review. Biofouling, 17, 73-86. http://dx.doi.org/10.1080/08927010109378466

[15] Konstantinou, I.K. and Albanis, T.A. (2004) Worldwide Occurrence and Effects of Antifouling Paint Booster Biocides in the Aquatic Environment: A Review. Environment International, 30, 235-248. 
http://dx.doi.org/10.1016/S0160-4120(03)00176-4

[16] Karlsson, J. and Eklund, B. (2004) New Biocide-Free and Anti-Fouling Paints Are Toxic. Marine Pollution Bulletin, 49, 456-464. http://dx.doi.org/10.1016/j.marpolbul.2004.02.034

[17] Mochida, K., Ito, K., Harino, H., Kakuno, A. and Fujii, K. (2006) Acute Toxicity of Pyrithione Antifouling Biocides and Joint Toxicity with Copper to Red Sea Bream (Pagrus major) and Toy Shrimp (Heptacarpus futilirostris). Environmental Toxicology and Chemistry, 25, 3058-3064. http://dx.doi.org/10.1897/05-688R.1

[18] Gatidou, T.G. and Thomaidis, N.S. (2007) Evaluation of Single and Joint Toxic Effects of Two Antifouling Biocides, Their Main Metabolites and Copper Using Phytoplankton Bioassays. Aquatic Toxicology, 85, 185-191. http://dx.doi.org/10.1016/j.aquatox.2007.09.002

[19] Karlsson, J., Ytreberg, E. and Eklund, B. (2010) Toxicity of Anti-Fouling Paints for Use on Ships and Leisure Boats to Non-Target Organisms Representing Three Trophic Levels. Environmental Pollution, 158, 681-687. http://dx.doi.org/10.1016/j.envpol.2009.10.024

[20] (1998) Concerning the Placing of Biocidal Products on the Market. European Council Directive 98/9/EC, Brussels.

[21] Okamura, H., Aoyama, I., Liu, D., Maquire, R.J., Pacepavivius, G.I. and Lau, Y.L. (2000) Fate and Ecotoxicity of the New Antifouling Compound Irgasol 1051 in the Aquatic Environment. Water Research, 34, 3523-3530. http://dx.doi.org/10.1016/S0043-1354(00)00095-6

[22] Férnandez-Alba, A.R., Hernando, M.D., Piedra, L. and Chisti, Y. (2002) Toxicity Evaluation of Single and Mixed Anti-Fouling Biocides Measured with Acute Toxicity Bioassays. Analytica Chimica Acta, 456, 303-312. http://dx.doi.org/10.1016/S0043-1354(00)00095-6

[23] Grunnet, K.S. and Dahllöf, I. (2005) Environmental Fate of the Antifouling Compound Zinc Pyrithione in Seawater. Environmental Toxicology and Chemistry, 24, 3001-3006. http://dx.doi.org/10.1897/04-627R.1

[24] Myers, J.H., Gunthorpe, L., Allinson, G. and Duda, S. (2006) Effects of Antifouling Biocides to the Germination and Growth of the Marine macroalga, Hormosira banksii (Turner) Desicaine. Marine Pollution Bulletin, 52, 1048-1055. http://dx.doi.org/10.1016/j.marpolbul.2006.01.010

[25] Thouvenin, M., Peron, J.J., Langlois, V., Guerrin, P., Langlois, J.Y. and Vallee-Rehel, K. (2002) Formulation and Antifouling Activity of Marine Paints: A Study by a Statistically Based Experiments Plan. Progress in Organic Coatings, 44, 85-92. http://dx.doi.org/10.1016/S0300-9440(01)00247-8

[26] Thouvenin, M., Peron, J.J., Charreteur, C., Guerrin, P., Langlois, J.Y. and Vallee-Rehel, K. (2002) A Study of the Biocide Release from Antifouling Paints. Progress in Organic Coatings, 44, 75-83. http://dx.doi.org/10.1016/S0300-9440(01)00246-6

[27] Karlsson, J., Breitholtz, M. and Eklund, B. (2006) A Practical Ranking System to Compare Toxicity of Anti-Fouling Paints. Marine Pollution Bulletin, 52, 1661-1667. http://dx.doi.org/10.1016/j.marpolbul.2006.06.007

[28] Kill, S., Johansen-Dam, K., Weinell, C.E. and Pedersen, M.S. (2002) Seawater-Soluble Pigments and Their Potential Use in Self-Polishing Antifouling Paints: Simulation-Based Screening Tool. Progress in Organic Coating, 45, 423434. http://dx.doi.org/10.1016/S0300-9440(02)00146-7

[29] Katranitsas, A., Castritsi-Catharios, J. and Persoone, G. (2003) The Effects of a Copper-Based Antifouling Paint on Mortality and Enzymatic Activity of a Non-Target Marine Organism. Marine Pollution Bulletin, 46, 1491-1494. http://dx.doi.org/10.1016/S0025-326X(03)00253-4

[30] Löschau, M. and Krätke, R. (2005) Efficacy and Toxicity of Self-Polishing Biocide-Free Antifouling Paints. Environmental Pollution, 138, 260-267. http://dx.doi.org/10.1016/S0025-326X(03)00253-4

[31] Castritsi-Catharios, J., Bourdaniotis, N. and Persoone, G. (2007) A New Simple Method with High Precision for Determining the Toxicity of Antifouling Paints on Brine Shrimp Larvae (Artemia): First Results. Chemosphere, 67, 1127-1132. http://dx.doi.org/10.1016/j.chemosphere.2006.11.033

[32] Brix, K.V., Gerdes, R.M., Adams, W.J. and Grosell, M. (2006) Effects of Copper, Cadmium, and Zinc on the Hatching Success of Brine Shrimp (Artemia franciscana). Archives of Environmental Contamination and Toxicology, 51, 580-583. http://dx.doi.org/10.1007/s00244-005-0244-z

[33] Barahona, M.V. and Sanchez-Fortun, S. (1999) Toxicity of Carbamates to the Brine Shrimp Artemia salina and the Effect of Atropine, BW284c51, iso-OMPA and 2-PAM on carbaryl toxicity. Environmental Pollution, 104, 469-476. http://dx.doi.org/10.1016/S0269-7491(98)00152-3

[34] Persoone, G. and Castritsi-Catharios, J. (1987) A Simple Bioassay with Artemia Larvae to Determine the Acute Toxicity of Antifouling Paints. Water Research, 23, 893-897.

[35] Castritsi-Catharios, J., Katsorchis, T., Marakis, S., Koukoulis, D. and Kafetzidakis, A. (1987) Acute Toxicity Tests with Dispersants and Oil Dispersant Mixtures. MAP Technical Reports Series (UNEP) No. 10/UNEP, Mediterranean Action Plan, F.A.O., Rome, 89-107. 
[36] Di Toro, D.M., Allen, H.E., Bergman, H.L., Meyer, J.S., Paquin, P.R. and Santore, R.C. (2001) Biotic Ligand Model of the Acute Toxicity of Metals. 1. Technical basis. Environmental Toxicology and Chemistry, 20, 2383-2396. http://dx.doi.org/10.1002/etc.5620201034

[37] Santore, R.C., Di Toro, D.M., Paquin, P.R. and Allen, H.E. (2001) Biotic Ligand Model of the Acute Toxicity of Metals. 2. Application to Acute Copper Toxicity in Freshwater Fish and Daphnia. Environmental Toxicology and Chemistry, 20, 2397-2402. http://dx.doi.org/10.1897/1551-5028(2001)020<2397:BLMOTA >2.0.CO;2

[38] Koutsaftis, A. and Aoyama, I. (2008) Toxicity of Diuron and Copper Pyrithione on the Brine Shrimp, Artemia franciscana: The Effects of Temperature and Salinity. Journal of Environmental Science and Health, Part A, 43, 1581-1585. http://dx.doi.org/10.1080/10934520802329794

[39] Koutsaftis, A. and Aoyama, I. (2007) Toxicity of Four Antifouling Biocides and Their Mixtures on the Brine Shrimp Artemia salina. Science of the Total Environment, 387, 166-174. http://dx.doi.org/10.1016/j.scitotenv.2007.07.023

[40] Koutsaftis, A. and Aoyama, I. (2006) The Interactive Effects of Binary Mixtures of Three Antifouling Biocides and Three Heavy Metals against the Marine Algae Chaetoceros gracilis. Environmental Toxicology, 21, 432-439. http://dx.doi.org/10.1002/tox.20202

[41] Xu, X., Wang, X., Li, Y., Wang, Y. and Wang, Y. (2011) Acute Toxicity and Synergism of Binary Mixtures of Antifouling Biocides with Heavy Metals to Embryos of Sea Urchin Glyptocidaris crenularis. Human and Experimental Toxicology, 30, 1013-1021.

[42] Chambers, L.D., Stokes, K.R., Walsh, F.C. and Wood, R.J.K. (2006) Modern Approaches to Marine Antifouling Coatings. Surface and Coating Technology, 201, 3642-3652. http://dx.doi.org/10.1016/j.surfcoat.2006.08.129

[43] Townsin, R.L. (2003) The Ship Hull Fouling Penalty. Biofouling, 19, 9-15. http://dx.doi.org/10.1080/0892701031000088535

[44] Yebra, D.M., Kiil, S., Dam-Johansen, K. and Weinell, K. (2005) Reaction Rate Estimation of Controlled Release Antifouling Paint Binders: Rosin Based Systems. Progress in Organic Coatings, 53, 256-275. http://dx.doi.org/10.1016/j.porgcoat.2005.03.008

[45] Kamaya, Y., Tokita, N. and Suzuki, K. (2005) Effects of Dehydroabietic Acid and Abietic Acid on Survival, Reproduction, and Growth of the Crustacean Daphnia magna. Ecotoxicology and Environmental Safety, 61, 83-88. http://dx.doi.org/10.1016/j.ecoenv.2004.07.007

[46] Omae, I. (2003) Organotin Antifouling Paints and Their Alternatives. Applied Organometalic Chemistry, 17, 81-105. http://dx.doi.org/10.1002/aoc.396

[47] Callow, M.E. and Willingham, G.L. (1996) Degradation of Antifouling Biocides. Biofouling, 10, 239-249. http://dx.doi.org/10.1080/08927019609386283

[48] Okamura, H. (2002) Photodegradation of the Antifouling Compounds Irgarol 1051 and Diuron Released from a Commercial Antifouling Paint. Chemosphere, 48, 43-50. http://dx.doi.org/10.1016/S0045-6535(02)00025-5

[49] Comber, S.D.W., Gardner, M.J. and Boxall, A.B.A. (2002) Survey of Four Marine Antifoulant Constituents (copper, Zinc, Diuron and Irgarol 1051) in Two UK Estuaries. Journal of Environmental Monitoring, 4, 417-425. http://dx.doi.org/10.1039/b202019j

[50] Alyuruk, H. and Cavas, L. (2013) Toxicities of Diuron and Irgarol on the Hatchability and Early Stage Development of Artemia salina. Turkish Journal of Biology, 37, 151-157.

[51] Callow, M.E. and Finlay, J.A. (1995) A Simple Method to Evaluate the Potential for Degradation of Antifouling Biocides. Biofouling, 9, 153-165. http://dx.doi.org/10.1080/08927019509378299

[52] Voulvoulis, N., Scrimshaw, M.D. and Lester, J.N. (2000) Occurrence of Four Biocides Utilized in Antifouling Paints, as Alternatives to Organotin Compounds in Waters and Sediments of a Commercial Estuary in the UK. Marine Pollution Bulletin, 40, 938-946. http://dx.doi.org/10.1016/S0025-326X(00)00034-5

[53] Voulvoulis, N., Scrimshaw, M.D. and Lester, J.N. (2002) Partitioning of Selected Antifouling Biocides in the Aquatic Environment. Marine Environmental Research, 53, 1-16. http://dx.doi.org/10.1016/S0141-1136(01)00102-7

[54] Hamwijk, C., Schouten, A., Foekema, E.M., Ravensberg, J.C., Collombon, M.T., Schmidt, K. and Kugler, M. (2005) Monitoring of the Booster Biocide Dichlofluanid in Water and Marine Sediment of Greek Marinas. Chemosphere, 60, 1316-1324. http://dx.doi.org/10.1016/j.chemosphere.2005.01.072

[55] White, S.L. and Rainbow, P.S. (1982) Regulation and Accumulation of Copper, Zinc and Cadmium by the Shrimp Palaemon elegans. Marine Ecolology Progress Series, 8, 95-101. http://dx.doi.org/10.3354/meps008095

[56] Santos, M.H.S., da Cunda, N.T. and Bianchini, A. (2000) Effects of Copper and Zinc on Growth, Feeding and Oxygen Consumption of Farfantepenaeus paulensis Postlarvae (Decapoda: Penaeidae). Journal of Experimental Marine Biology and Ecology, 247, 233-242. http://dx.doi.org/10.1016/S0022-0981(00)00152-0

[57] Nebeker, A.V. and Schuytema, G.S. (1998) Chronic Effects of the Herbicide Diuron on Freshwater Cladocerans, Am- 
phipods, Midges, Minnows, Worms and Snails. Archives of Environmental Contamination and Toxicology, 35, 441446. http://dx.doi.org/10.1007/s002449900400

[58] Kerster, H.W. and Schaeffer, D.J. (1983) Brine Shrimp (Artemia salina) Nauplii as a Teratogen Test System. Ecotoxicology and Environmental Safety, 7, 342-349. http://dx.doi.org/10.1016/0147-6513(83)90079-9

[59] Castritsi-Catharios, J., Syriou, V., Miliou, H. and Zouganelis, G.D. (2013) Toxicity Effects of Bisphenol A to the Nauplii of the Brine Shrimp Artemia franciscana. Journal of Biological Research-Thessaloniki, 19, 38-45. 